Original scientific paper - Izvorni znanstveni rad

UDK: 637.1

\title{
Multiple-criteria approach of evaluation of milk farm models in Bosnia and Herzegovina
}

doi: $10.15567 /$ mljekarstvo.2016.0305

\author{
Črtomir Rozman ${ }^{1}$, Zoran Grgić2 ${ }^{*}$, Aleksandar Maksimović ${ }^{3}$, \\ Ferhat Ćejvanović ${ }^{4}$, Adis Puška ${ }^{3}$, Branka Šakić Bobić ${ }^{2}$
}

${ }^{1}$ Faculty of Agriculture and Life Sciences, University of Maribor, Pivola 10, 2311 Hoče, Slovenia ${ }^{2}$ University of Zagreb Faculty of Agriculture, Svetošimunska cesta 25, 10000 Zagreb, Croatia ${ }^{3}$ College of Computer Science and Business Communications EMPIRICA, Bulevara mira 10, 76100 Brcko distrikt Bosnia and Herzegovina ${ }^{4}$ Government of Brcko District of B\&H, Bulevara mira 10, 76100 Brcko distrikt Bosnia and Herzegovina

Received - Prispjelo: 16.03.2016. Accepted - Prihvaćeno: 16.05.2016.

\begin{abstract}
Cattle breeding is a very important part of agricultural production in Bosnia and Herzegovina $(\mathrm{B} \& \mathrm{H})$, and milk production has a vital place in cattle breeding production. From an economic point of view, milk production is interesting as it is a daily production which presupposes faster marketing, which accelerates capital movement in agriculture, which in turn enhances liquidity. This research uses analyses of the existing state in milk production. The collected data are processed and cost calculation has been designed which enables the analysis of economic indicators of 4 dairy farm production models in $\mathrm{B} \& \mathrm{H}$. Based on the collected data on features and values of dairy farm production models in $\mathrm{B} \& \mathrm{H}$ an analysis of expert evaluation was conducted as input data for DEXi method. The aim of this paper is to ascertain the basic indicators of business success of 4 dairy farm production models in B\&H. Production-ecological, economic and socio-political features of the mentioned dairy farm models were analyzed. Based on the used criteria a rate of dairy farm production models using DEXi method was conducted. The results of the research in this paper using DEXi method show that the best model for dairy farm is model number four, which includes 45 milk cows.
\end{abstract}

Key words: dairy farms, production models, economic indicators, DEXi, Bosnia and Herzegovina

\section{Introduction}

While deciding about investment into farms of dairy cows, it's necessary to consider all different data and it is crucial to perceive all aspects of investment. With that purpose, in this paper was carried out the multi-criterial evaluation of different dairy farm models. Based on variety of segments that can be used upon choosing the dairy farm model, this problem of decision making could be solved by utilization of multi-criteria analysis method (MCDA).

MCDA is being used in situations when it's required to decide about more different alternatives, which are available, and all these alternatives are evaluated by different criteria. In order to finalize the decision about choosing the production model of dairy farms, all criteria must be considered and each alternative must be evaluated - by that criteria. As the final outcome of MCDA utilization there's a result which is ranking the alternatives from the best to the weaker one. This order is obtained on the basis of compromise solution of investment problems which takes into account all goals of decision making.

MCDA method can be used when the values are qualitative (non-numerical, linguistic) and quantitative (numerical). The majority of methods for multi-criterial decision making (MCDM) are using 
numerical criteria values where the alternatives order is done by simply adding the sum weights, such as methods: simple additive method (SAW), TOPSIS, VIKOR, MAUT and others. These methods are improved via fuzzy logic with possibility of using linguistic (non-numerical) values in determining the criteria value.

The main difference between DEX method and other MCDA methods is that DEX method does not transform the linguistic values, than it uses "if-then" rules. The result of this method is linguistic value, and not numerical. Consequently, utilization of this method is more beneficial comparing to MCDA methods because it can use different linguistic values, and the result itself is in the shape of linguistic value thus approaching the human way of thinking.

When using these methods, the most used method in agriculture was method of analytic hierarchy process (AHP). The examples of using this method upon choosing production models of dairy farms are possible to find in next papers: Rozman et al., 2015; Agha et al., 2012; Van Chuong, 2011; Agha, 2011; Srđević et al., 2004. Unlike AHP method, the deciding problems can be described qualitatively using the non-numerical values and "if-then" rules. As this paper will use qualitative non-numerical variables, the logical selection would be DEX method. It's possible to individually use these methods, but they can also be used together (Košljar and Rajkovič 2014; Pažek et al., 2010). In this paper, by using the DEX method for decision making there were selected dairy farms production models which gives the top results.

\section{Materials and methods}

This research is based on decision making analysis by using more criteria, where the alternatives are production models of dairy farms. As the decision making support, the hierarchical MCDM model will be used through a combination of expert opinions and economic analysis of dairy farms production models.

The usage of this method includes two basic stages: problem development, usage of evaluation model and analysis of decision making alternatives. At first, a decision making model will be installed, which will be used to evaluate four alternatives of dairy farm production models. This will be done by using the DEX methodology, and it will choose the top model for dairy farms selection.

\section{Data collection and an economic analysis of dairy farm production models in Bosnia and Herzegovina}

Data for dairy farm capacity and production analysis were obtained through research of farms in Bosnia and Herzegovina. Researched farms were engaged in dairy cows rearing. The data were obtained through surveys (polls) that were conducted on an expert sample of 50 farms, in 2016. In Bosnia and Herzegovina, the milk yield per cow is low. The measures to increase milk production efficiency consists of improved cow feeding, as well as rearing which will result in better milk production, to the level of certain genetic base (Oplanić et al., 2008).

Table 1. Characteristics and values of dairy farms production models in Bosnia and Herzegovina

\begin{tabular}{|c|c|c|c|c|}
\hline \multirow{2}{*}{ Model characteristics } & \multicolumn{4}{|c|}{ Production model of dairy farms } \\
\hline & $1^{\text {st }}$ & $2^{\text {nd }}$ & $3^{\text {rd }}$ & $4^{\text {th }}$ \\
\hline Number of dairy cows & 5 & 15 & 25 & 45 \\
\hline Stall area $\left(\mathrm{m}^{2}\right)$ & 40 & 200 & 350 & 620 \\
\hline Farming system & At chain & Free & Free & Free \\
\hline $\begin{array}{c}\text { Object and Equipement } \\
\text { investment value }(€)\end{array}$ & 7000 & 35000 & 62000 & 109000 \\
\hline $\begin{array}{l}\text { Milk production per cow } \\
\text { (L) }\end{array}$ & 3500 & 4500 & 5500 & 5500 \\
\hline $\begin{array}{l}\text { Annual production for } \\
\text { market }\end{array}$ & $\begin{array}{c}17500 \text { L milk } \\
4 \text { calves } \\
\text { (up to } 10 \text { days) }\end{array}$ & $\begin{array}{c}67500 \text { L milk } \\
12 \text { calves } \\
\text { (up to } 10 \text { days) }\end{array}$ & $\begin{array}{l}137500 \text { L milk } \\
20 \text { calves } \\
\text { (up to } 10 \text { days) }\end{array}$ & $\begin{array}{l}247500 \text { L milk } \\
36 \text { calves } \\
\text { (up to } 10 \text { days) }\end{array}$ \\
\hline Annual working hours & 2200 & 3100 & 3800 & 5300 \\
\hline
\end{tabular}


As a main factor in an income increase of milk production with unchanged sales price, feeding systems were defined (Očić et al., 2011). In Table 1 are presented the characteristics and values of dairy farms production models in Bosnia and Herzegovina.

First production model of dairy cows includes 5 dairy cows in humble barn facility kept in one place by chain, with relatively low income and milk production of up to 3500 liters/year per head.

The second production model includes 15 dairy cows in sheds building area of 200 square meters and with a level of milk production of 4,500 liters of milk per cow.

In the third production model dairy farms have kept 25 dairy cows in sheds building area of 350 square meters, with a relatively high amount of milk production of 5,500 liters of milk per cow. Fourth production model consists of 45 dairy cows in object with surface of 620 square meters, where cows are free and produce 5500 liters of milk/year per head.

Capacities and production in presented production models of dairy farms are both proportional to the farm size. By increasing the farm in second, third and fourth production model, the values of fixed assets involved and amount of input increase as well.

In Table 2 are presented the values of economic indicators of dairy farms production models, annually.
The Table 2 shows that values of production grow from model one to model four. Variable costs also have proportional relationship with production increment from model one to model four. Gross margin (including the amortization) has increase from model one to model four. Income per hour ranges between $€ 0.70$ in model one, and $€ 7.69$ in model four. Price is the highest at production model one ( $0.3029 € /$ liter) while the price at production models three and four is $0.21 € /$ liter.

When analyzing the investment indicators of dairy farms production models, it can be determined that net present value, at production model one, is negative. Therefore, such project is not acceptable. Net present value of production model two is positive, but still has no high value.

Production model three has net present value of $€ 32,883.49$ which represents an acceptable project. Production model four has high net present value with the amount of $€ 62,885.50$ which makes this model as the most acceptable analyzed production model. According to the net present value, the internal rate of return has the same trend. Since the discount rate in calculations was $6 \%$, internal rate (Fabozzi i Peterson, 2003) is lower in production model one and, as such, is rated as unacceptable investments.

Table 2. Values of economic indicators of dairy farms production models - annually ( $€$ )

\begin{tabular}{ccccc}
\hline \multirow{2}{*}{ Indicators } & \multicolumn{4}{c}{ Value per dairy farms model $(€)$} \\
\cline { 2 - 5 } & 1. & 2. & 3. & 4. \\
\hline Purchase price* & 0.27 & 0.27 & 0.27 & 0.27 \\
\hline Production value & 4,725 & 18,225 & 37,125 & 66,825 \\
\hline Value of calves up to 10 days & 720 & 2,160 & 3,600 & 6,480 \\
\hline Milk incentive (0,08 $€ / \mathrm{L})$ & 1,400 & 5,400 & 11,000 & 19,800 \\
\hline Total receipts & 6,845 & 25,785 & 51,725 & 93,105 \\
\hline Variable costs & 4,600 & 13,800 & 23,000 & 41,400 \\
\hline Amortization & 700 & 3,500 & 6,200 & 10,900 \\
\hline (time method for a period of 10 years) & 1,545 & 8,485 & 22,525 & 40,805 \\
\hline Gross margin (amortization included) & 0.70 & 2.73 & 5.92 & 7.69 \\
\hline Income per hour, based on gross margin & 0.30 & 0.26 & 0.21 & 0.21 \\
\hline Price of milk (per L) & -491.90 & 741.91 & $32,883.49$ & $62,885.50$ \\
\hline The present net value - $€$ (NPV) & 3.38 & 6.78 & 23.88 & 25.33 \\
\hline Internal Rate of Return (IRR) & & & \\
\hline
\end{tabular}

*Purchase price in January 2016. 
Production model two has internal rate of return somewhat greater than $6 \%$ which is tolerated. Internal rate of return in production model three $(23.88 \%)$ and four $(25.33 \%)$ has great values so these production models are rated as acceptable. Based on the obtained data about characteristics and values of dairy farms production models in Bosnia and Herzegovina, as well as received results of economic indicators, a further analysis of dairy farms production model's economic success has been carried out - using the DEX method.

\section{Methodology of multi-criteria modeling with DEX method}

DEX method allows description of hierarchy attributes in conceptual model and rules aggregation between attribute that is usable on problems of real decision making (Bohanec and Rajkovic, 1999; Kontic Bohanec and Urbancic, 2006). DEX combines traditional MCDM methodology with expert system elements and machine language. The most important characteristic is qualitative variables usage ability and DEX method provides descriptive results and uses variables whose values are: low, high, acceptable, unacceptable, etc. It also allows usage of various scales of qualitative variables. DEX method usage isn't limited to just qualitative variables usage, but it's possible to transform the quantitative variables to qualitative variables by using "if-then" decision making method. DEX method utilization is done by DEXi software.

DEX model is usually built through following phases (Bohanec, 2003):

1. Model making is hierarchically decomposed into less complex individual problems. Decision making problem is presented as decisions tree (image 1) which represents hierarchical model structure. Terminal nodes of model tree represent input, while the root node represents main output regarding overall ranking of alternatives which in this case stands for sort value of milk cow farms.

2. Each sub problem is presented with qualitative attribute with specific value scale that consists of two words (image 2). The scale measures the value of certain criteria and assigned qualitative value.
3. Affiliation functions are defined for each attribute. In DEX method these functions are usually set through summary sub-criteria assessment (image 3).

\section{DEX model of dairy farm choices in Bosnia and Herzegovina}

DEX model is based on expert evaluations. Using expert evaluation and calculation, a hierarchical model will be formed for choice evaluation of the best model of dairy farm (image 1).

The analysis of the dairy farm model in the primary evaluation takes into account three dimensions in determining the criteria tree (upon determining weak criteria):

1. production-environmental

2. economic

3. social and political criteria

Each of mentioned criteria has additional sub criteria which are presented as follows:

1. First part of attribute tree consists of Production-environmental criteria, which is firstly divided into production and technical criteria. Production criteria are described with sub criteria of dairy cows breeding technology and level of mechanization. Ecological criteria are described by sub criteria, utilization of ecological standards and impact on environment.

Image 1. The attribute tree of dairy farm model choice in Bosnia and Herzegovina

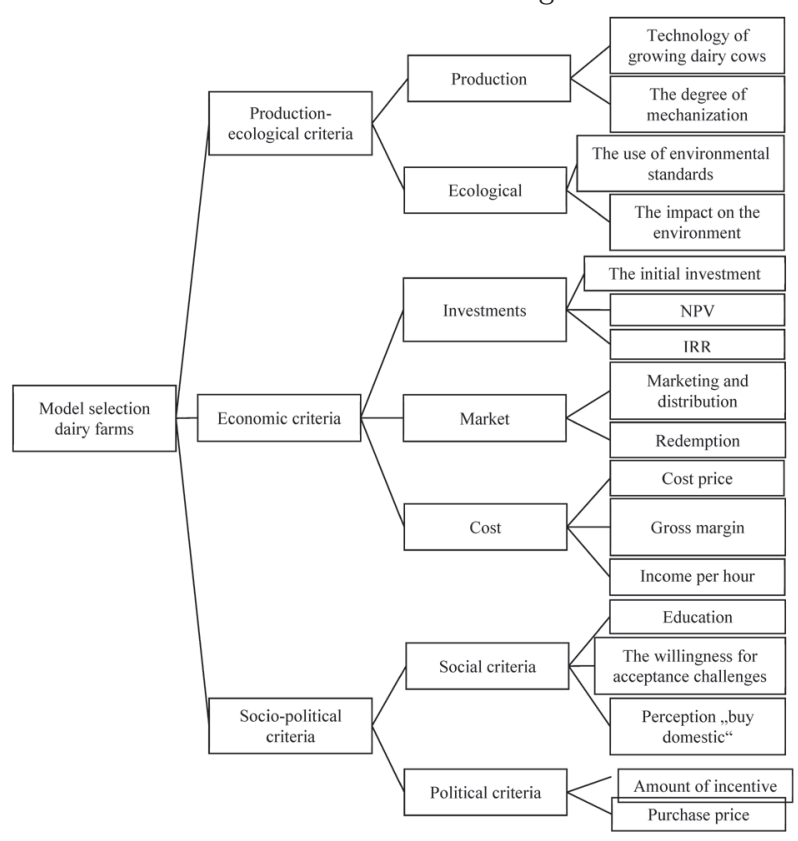


2. Second part of attribute tree consists of economic criteria which are made of three sub criteria: investment, market criteria, and costs criteria. Investment is described with following attributes: net present value (NPV), internal rate of return (IRR) and initial investment. Market criteria are described with following attributes: marketing, distribution and purchase of milk. Costs criteria are determined by following attributes: price, gross margin and income per hour of work.

3. Third part of attribute three is a social and political criterion which is firstly divided into social and political criteria. Social criteria are described by following attributes: education, willingness to accept the challenge and perception to purchase domestic products. Political criteria are described by following attributes: incentive amount and purchase price.

Each attribute has a range of possible qualitative values (image 2). For example, if you take net present value (NPV), its value can be positive and negative. If it's negative, then the alternative is unacceptable and vice versa. In addition to this, it's possible to define the NPV's value size with low value, middle value and high value, and thus transform the quantitative values into qualitative values (Rozman et al., 2009).

In the last step of DEX models development, the decision making rules have been defined. Decision making rules are defined by aggregation of model value, from input through middle attributes all to the root. Decision making rules are defined for all internal attributes, including the root.

Image 2. Attribute model scale of dairy farms selection in Bosnia and Herzegovina

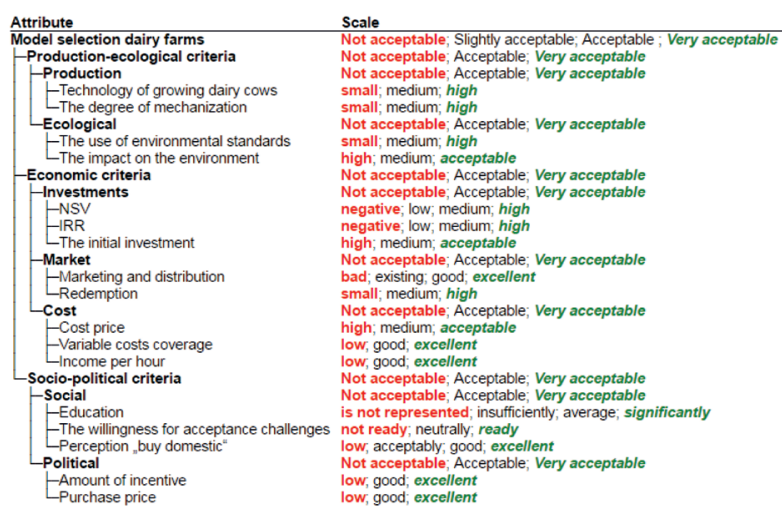

The image 3 shows the function of only one utility and this is the first level from root where the main decision making criteria are integrated. On the basis of this function a determination will be given about dairy farms production models, as: not acceptable, partly acceptable, medium acceptable, acceptable and extremely acceptable.

On the basis of utility function, the DEXi evaluation weights are determined by using the linear regression method (Bohanec, 2008). This utility function uses the following rules:

- attribute value will be unacceptable if two of three criteria are irrelevant

- attribute value will be partly acceptable if one of criteria is irrelevant, one of criteria is extremely important, one criteria is irrelevant, and the last two criteria are important.

- attribute value will be acceptable if one criteria is irrelevant while the other two criteria are extremely important, and when all three criteria are important.

- attribute value will be extremely acceptable if two or more criteria are extremely important while the other criteria are important. If one of criteria is irrelevant the final attribute value cannot be extremely acceptable.

\section{Results and discussion}

In this DEXi model four dairy farm production models are analyzed, as an alternative for the best dairy farm model selection. Production models (from one to four), their values and characteristics by DEX model are presented on image 4 . Presented dairy farm production models are analyzed with

Image 3. An example of weighting the criteria of dairy farm models

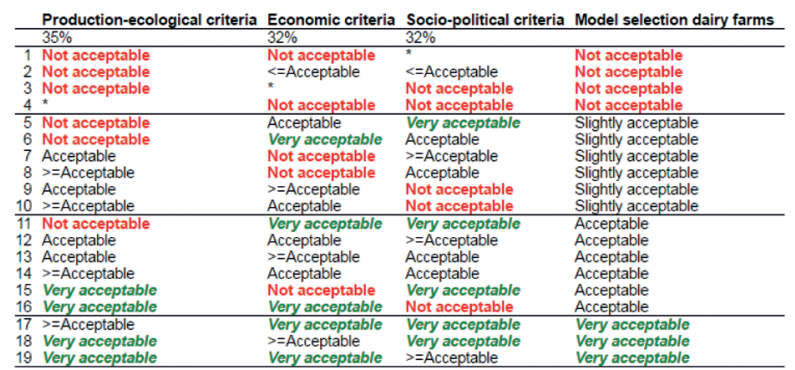


expert opinion and economic analysis. With this methodology it came to dairy farm production model comparison by default attributes.

If we take, for example, political criteria - all results of this criterion are the same regardless of livestock number at farm. This occurs because it's not being taken care of how much livestock is there, but the incentive and total price is defined as total for whole production. No special attention is given to farm size. At social criteria, one can see that of all attributes the best rating was assigned to model four (4) while the worst rating was for model one (1).

By looking at economic criteria it can be said that the market and cost criteria are in the same situation as social criteria, meaning that model four (4) gives the best results while model one (1) shows the worst results. Exception applies to results upon investment. The reason for that is that the most financial resources must be assigned to model four (4) for installing the production, while it's the opposite for model one (1).

At production and ecological criteria it can be seen that ecological sub criteria has minor differences compared to other attributes. When we look at the impact on environment, the greatest impact stands with model four (4) while the least is at model one (1). By using the attributes of ecological standards, one will obtain totally different result meaning that the greatest care is being taken at model four (4) while the least attention has been paid at model one (1). At production criteria both attributes have the same result, meaning that the model four (4) has the high-tech of breeding and mechanization level, while the model one (1) is opposite. At all attributes described by sub criteria's, model two (2) and three (3) take the central place.

On the basis of individual results of certain criteria, image 5 shows the cumulative result in the decision making process regarding dairy farm production models selection in Bosnia and Herzegovina.

As can be seen from image 5 , model one (1) is unacceptable, models two (2) and three (3) are acceptable, while the model four (4) is extremely acceptable. Logical selection of decision maker, based on these results, is that upon selecting dairy farm production models model four (4) is used as the top ranked by DEXi method.

Image 4. DEXi results for dairy farm production models in Bosnia and Herzegovina

\begin{tabular}{|c|c|c|c|c|}
\hline Attribute & Model 1 & Model 2 & Model 3 & Model 4 \\
\hline Model selection dairy farms & Not acceptable & Acceptable & & Very acceptable \\
\hline $\begin{array}{l}\text { Production-ecological criteria } \\
\text { Production }\end{array}$ & $\begin{array}{l}\text { Not acceptable } \\
\text { Not acceptable }\end{array}$ & Vory acceptable & eptable & Very acceptable \\
\hline & & $\begin{array}{l}\text { Acceptable } \\
\text { medium }\end{array}$ & $\begin{array}{l}\text { Accepta } \\
\text { medium }\end{array}$ & $\begin{array}{l}\text { Very acceptable } \\
\text { high }\end{array}$ \\
\hline The degree of mechanization & $\begin{array}{l}\text { Smail } \\
\text { small }\end{array}$ & medium & $\begin{array}{l}\text { medum } \\
\text { medium }\end{array}$ & $\begin{array}{l}\text { nlgn } \\
\text { high }\end{array}$ \\
\hline Ecological & Acceptable & Very acceptable & Acceptable & Very acceptable \\
\hline $\begin{array}{l}\text { The use of environmental standards } \\
\text { The impact on the environment }\end{array}$ & $\begin{array}{l}\text { small } \\
\text { accoptable }\end{array}$ & medium & $\begin{array}{l}\text { medium } \\
\text { medium }\end{array}$ & $\begin{array}{l}\text { high } \\
\text { medium }\end{array}$ \\
\hline conomic criteria & Not acceptable & Acceptable & Acceptable & Very acceptable \\
\hline -Investments & Not acceptable & Acceptable & Acceptable & Very acceptable \\
\hline $\begin{array}{l}\text {-NSV } \\
\text { - IRR }\end{array}$ & $\begin{array}{l}\text { negative } \\
\text { negative }\end{array}$ & low & $\begin{array}{l}\text { medium } \\
\text { medium }\end{array}$ & 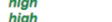 \\
\hline -The initial investment & acceptable & medium & medium & high \\
\hline -Market & Not acceptable & $\begin{array}{l}\text { Acceptable } \\
\text { existing }\end{array}$ & Acceptable & Very acceptable \\
\hline $\begin{array}{l}\text {-Marketing and distrioution } \\
\text { Redemption }\end{array}$ & $\begin{array}{l}\text { bad } \\
\text { small }\end{array}$ & $\begin{array}{l}\text { exsung } \\
\text { medium }\end{array}$ & $\begin{array}{l}\text { exisung } \\
\text { medium }\end{array}$ & $\begin{array}{l}\text { good } \\
\text { high }\end{array}$ \\
\hline - Cost & Not acceptable & Acceptable & Very acceptable & Very acceptable \\
\hline $\begin{array}{l}\text { - Cost price } \\
\text {-Variale costs co: }\end{array}$ & $\begin{array}{l}\text { high } \\
\text { low }\end{array}$ & $\begin{array}{l}\text { medium } \\
\text { good }\end{array}$ & $\begin{array}{l}\text { acceptable } \\
\text { excellent }\end{array}$ & $\begin{array}{l}\text { acceptable } \\
\text { excellent }\end{array}$ \\
\hline Income per hour & & & excellent & excellent \\
\hline -Socio-political criteria & Not acceptable & Acceptable & Very accoptable & Vory acceptablo \\
\hline $\begin{array}{l}\text { Social } \\
\rightarrow \text { Education }\end{array}$ & $\begin{array}{l}\text { Not acceptable } \\
\text { is not represented }\end{array}$ & $\begin{array}{l}\text { Acceptable } \\
\text { insufficiently }\end{array}$ & $\begin{array}{l}\text { Very acceptable } \\
\text { average }\end{array}$ & $\begin{array}{l}\text { Very acceptable } \\
\text { significantl/ }\end{array}$ \\
\hline -The willingness for acceptance challenges & not ready & neutrally & $\begin{array}{l}\text { average } \\
\text { ready }\end{array}$ & $\begin{array}{l}\text { Slgnificanty } \\
\text { ready }\end{array}$ \\
\hline $\begin{array}{l}\text { LPerception „buy domestica } \\
\text {-Political }\end{array}$ & $\begin{array}{l}\text { acceptably } \\
\text { Acreptable }\end{array}$ & good & good & $\begin{array}{l}\text { excellent } \\
\text { Acceptable }\end{array}$ \\
\hline Political & $\begin{array}{l}\text { Accept } \\
\text { good }\end{array}$ & $\begin{array}{l}\text { Acceplable } \\
\text { good }\end{array}$ & $\begin{array}{l}\text { Acceptable } \\
\text { good }\end{array}$ & $\begin{array}{l}\text { Accepta } \\
\text { good }\end{array}$ \\
\hline Purchase price & & & & \\
\hline
\end{tabular}

Image 5. Graphical representation of final results selection dairy farms in Bosnia and Herzegovina

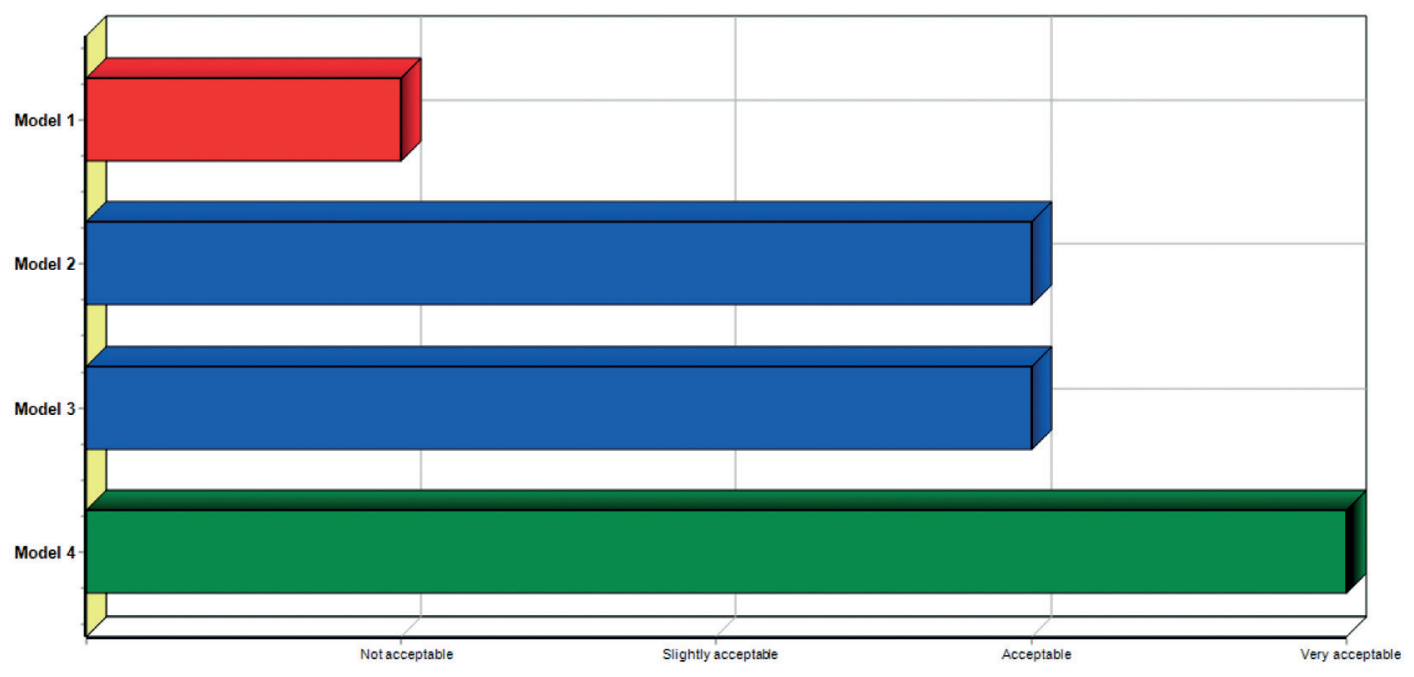




\section{DEXi model application in practice}

The significant characteristic of DEXi software is that the results can be presented through graphical interface where the data and evaluations can be shown on lower level of DEXi model, as well as seen how the data participate in overall rating. This characteristic is really important for evaluation of justification process.

Besides that, such analysis can be visualized very easy through different graphs. In our research, only the main criteria presented through radar graph have been taken (image 6), which demonstrated that the rating of certain dairy farm production models in accordance with established decision making rules - as shown on image 3.

As can be seen by using the radar graphs, production model one (1) shows that it's "irrelevant" at all criteria so the result of this model is only one point (dot). Production model two (2) shows that the criteria of economic and social-political is "important", while the production and ecological criteria is "extremely important". Production model three (3) shows that it's "important" at production-ecological and economic criteria, while it's "extremely important" at social and political criteria. Production model four (4) shows "extreme importance" at all criteria, however its graph is not equilateral triangle but it comes to line breaking between productionecological and socially-political. The reason for this is that the economic criteria, by using the attribute "investment", has got the "high" rating meaning the worst rating of that attribute.

By DEXi model utilization, investor receives important information about possible usage of different dairy farm production models, where it's possible to select the best model with default attributes, on the basis of results received from experts and economic analysis. An advantage of DEXi model is multi-functionality of default attributes upon decision making, where adhere multiple decision making criteria. Unlike classic way, where the decision making is based on only one criterion, here is observed by default criteria.

The deficiency of DEXi model is that it does not support criteria based on quantitative data, but only qualitative. For example, technical and financial criteria needed conversion from quantitative to qualitative criteria. Practical solution of this problem is assigning the specific rules by which the quantitative factors will transform to qualitative factors and be inserted into DEXi model.

Usage and development of DEXi model in decision making process of dairy farm production models selection could be combined with AHP methods or analytical network process (ANP), where the certain criteria would be evaluated with these methods and thus determine their weights. Value weights of criteria would be defined in DEXi model thus it would enable the acquisition of more accurate results at decision making.

\section{Conclusion}

In this paper we tried to take advantage of multi-criteria analysis to make informed decisions on the best dairy farms model for investors, using expert assessment and economic analysis of different production models dairy farms. DEXi methodology is based on qualitative indicators, attributes and functions in the form of rules and decisions that are appropriate for the evaluation and adoption of the best decisions.

The research is based on collected data of four dairy farm production model's characteristics and values. Economic analysis of collected data has been carried out using the economic indicators of dairy farm production models in Bosnia and Herzegovina.

Economic indicators such as purchase price, production value, total income, variable costs, amortization, gross margin, income per hour, price of milk (liter), net present value, and internal return rate have been presented in this research. Mentioned economic indicators have been used as input data in DEXi model for evaluation and selection of the best dairy farm production model in Bosnia and Herzegovina.

Using the DEXi model, in this paper has been stated that the best dairy farm production model is model four (4), while the production models three (3) and two (2) are acceptable. Production model one (1) is unacceptable for set criteria.

Milk production is significant agricultural activity, but the usage of DEXi model hasn't come to life so far while making a decision about rating and selection of dairy farm production models. 
Image 6. Graphical representation of main criteria for dairy farm production models in Bosnia and Herzegovina

Model 1

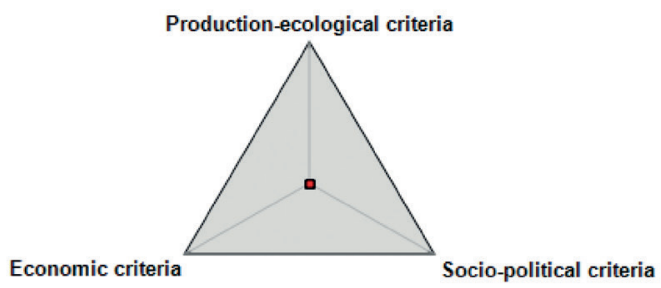

Model 3

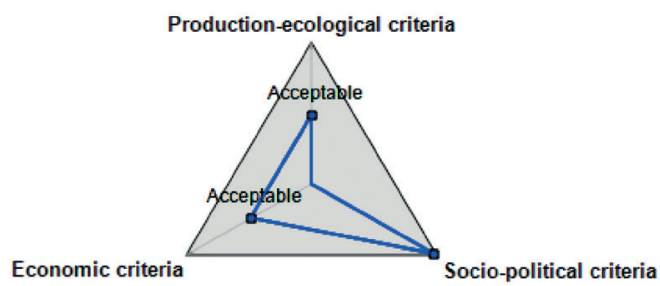

Model 2

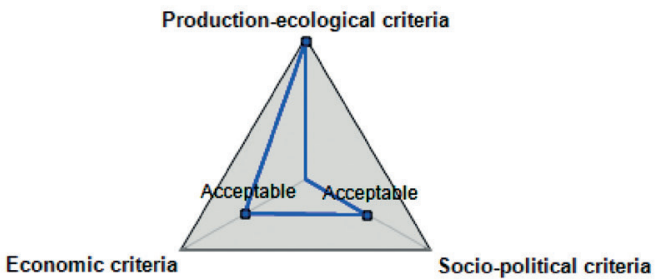

Model 4

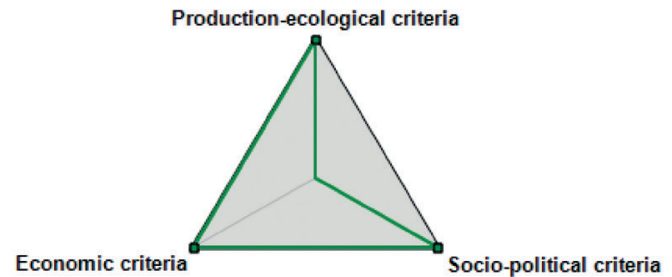

Therefore the author's intention is that this DEXi model finds its place when selecting dairy farm production models. In this research, the DEXi model is based on three main criteria, but it's possible to expand it with additional criteria that will be included in decision making tree.

Further development of DEXi model could be in integration with other methods, eg. AHP and ANP, where the criteria weights could be defined thus receiving more accurate results.

\section{Višekriterijski pristup ocjene modela mliječnih farmi u Bosni i Hercegovini}

\section{Sažetak}

Govedarstvo je vrlo značajna grana poljoprivredne proizvodnje $\mathrm{u}$ Bosni i Hercegovini, a proizvodnja mlijeka zauzima značajno mjesto u govedarskoj proizvodnji. Ekonomski gledano proizvodnja mlijeka je zanimljiva jer je to svakodnevna proizvodnja što praktično stvara pretpostavke bržeg plasmana na tržište, ubrzava obrt kapitala na poljoprivrednom gospodarstvu i pospješuje njegovu likvidnost. U istraživanju je korištena analiza postojećeg stanja u proizvodnji mlijeka. Prikupljeni su podaci o proizvodnji i izrađena je obračunska kalkulacija troškova proizvodnje koja omogućava analizu ekonomskih pokazatelja četiri proizvodna modela mliječnih farmi u Bosni i Hercegovini. Prema obilježjima i ekonomskim vrijednostima modela mliječnih farmi u Bosni i Hercegovini obavljena je ekspertna ocjena ulaznih podataka za DEXi metodu. Cilj rada je ustanoviti osnovne pokazatelje uspješnosti poslovanja četiri proizvodna modela mliječnih farmi u Bosni i Hercegovini. Analizirana su proizvodno-ekološka, ekonomska i socijalno-politička obilježja navedenih modela. $\mathrm{Na}$ osnovu odabranih kriterija obavljena je ocjena proizvodnih modela primjenom DEXi metode. Rezultati istraživanja $u$ ovom radu primjenom DEXi metode pokazuju da je najbolji model za mliječne farme model četiri koji uključuje 45 mliječnih krava.

Ključne riječi: mliječne farme, proizvodni modeli, ekonomski pokazatelji, DEXi, Bosna i Hercegovina

\section{Reference}

1. Agha, S.R., Latifa G.N., Nassar H.A., Shehada R.Y. (2012): Multi Criteria Governmental Crop Planning Problem: an Analytic Hierarchy Approach, Management 2 (4), 96-105.

2. Agha, S.R. (2011): A multi-criteria crop planning model based on the "resistive economy" characterizing the situation in Gaza Strip. $8^{\text {th }}$ International conference on Islamic economy and finance, Doha, Qatar, 1-22. 
3. Bohanec, M. (2008): DEXi: Program for multi-attribute decision making, user's manual, version 5.00. IJS Report DP-1 1897, Jožef Stefan Institute, Ljubljana, 2015., http://kt.ijs.si/MarkoBohanec/pub/DEXiManual500. pdf. Accessed 18.01.2016.

4. Bohanec, M., Rajkovic, V. (1999): Multi-attribute decision modeling: industrial applications of DEX, Informatica 23 (4), 487-491.

5. Fabozzi F.J., Peterson P.P. (2003): Financial Management and Analysis, John Wiley \& Sons.

6. Hung, H.L., Altschuld, J.W., Lee, Y.F (2008): Methodological and conceptual issues confronting a crosscountry Delphi study of educational program evaluation, Evaluation and Program Planning 31 (2), 191-198. doi: 10.1016/j.evalprogplan.2008.02.005

7. Košljar, T., Rajkovič, V. (2014): Primerjalna uporaba metod DEX in AHP v procesu odločanja, Informatika, 22(3), 147-151.

8. Kontić, B., Bohanec, M., Urbančič, T., 2006. An experiment in participative environmental decision making, The Environmentalist 26, 5-15. doi: 10.1007/s10669-006-5353-3

9. Očić, V., Šakić Bobić, B., Grgić Z. (2012): Utjecaj krmnoga slijeda na dohodak proizvodnje mlijeka, Mljekarstvo 62 (4), 261-268.
10. Oplanić, M., Radinović, S., Par, V., Tratnik, M. (2008): Ekonomska uspješnost uzgoja muznih krava na primjeru Istre, Agronomski glasnik 1, 21-32

11. Srdjevic, B., Srdjevic, Z., Kolarov, V. (2004): Group evaluation of walnut cultivars as a multicriterion decision-making process. In CIGR International Conference, Beijing, China, 11-14.

12. Pažek, K., Rozman, Č., Bavec, F., Borec, A., Bavec, M. (2010): A Multi-Criteria Decision Analysis Framework Tool for the Selection of Farm Business Models on Organic Mountain Farms, Journal of Sustainable Agriculture 34, 778-799. doi: 10.1080/10440046.2010.507531

13. Rozman, Č., Potočnik, M., Pažek, K., Borec, A., Majkovič, D., Bohanec, M. (2009): A multi-criteria assessment of tourist farm service quality, Tourism Management 30, 629-637. doi: 10.1016/j.tourman.2008.11.008

14. Rozman, Č., Hühner, M., Kolenko, M., Tojnko, S., Unuk, T., Pažek, K. (2015): Apple Variety Assessment with Analytical Hierarchy Process, Erwerbs-Obstbau 57 (2), 97-104. doi: 10.1007/s10341-015-0236-8

15. Van Chuong, H. (2011): Land Suitability Analysis and Evaluation for Production of Fruit Trees Using GIS Technology, Journal of Science, Hue University, 67 (4A), 13-22. 